\title{
Anxiety Stress and Fatigue in Hemodialysis Patient
}

\author{
$1^{\text {st }}$ Rumentalia Sulistni \\ Nursing Department \\ Poltekkes Kemenkes Palembang \\ Palembang, Indonesia \\ rumentaliasulistini@gmail.com
}

\author{
$2^{\text {nd }}$ Hanna DL Damanik \\ Nursing Department \\ Poltekkes Kemenkes Palembang \\ Palembang, Indonesia \\ hanna.1204@gmail.com
}

\author{
$3^{\text {rd }}$ Lukman \\ Nursing Department \\ Poltekkes Kemenkes Palembang \\ Palembang, Indonesia \\ lukman@poltekkespalembang.ac.id
}

Corresponding author : rumentaliasulistini@gmail.com

\begin{abstract}
Hemodialysis is a kidney function replacement therapy that aims to remove metabolic waste or certain toxins from human blood circulation. Patients with chronic renal failure who undergo hemodialysis therapy will experience various problems such as psychological disorders, including Self-Concept Disorders, Anxiety, Depression, and Grieving. This aims of study to determine the relationship between anxiety, stress and fatigue in hemodialysis patients. The design of this study was a cross sectional study. The sample studies consisted of 37 patients undergoing hemodialysis. the inclusion criteria were aged over 17 years, signed informed consent. Exclusion criteria were patients with neurological disorders and speech difficulties. The results of the study were more female respondents $\mathbf{( 5 6 . 8 \% )}$ than male respondents. Higher education respondents were $64.9 \%$ more dominant than those with low education. The average age was 52.16 years, with the lowest age being 24 years and the oldest being 78 years. The average length of hemodialysis was 32.95 months with the shortest being 1 month and the longest being 168 months. The average score of anxiety was 10.11 with the lowest score of 0 and the highest was 20 . The average score of stress was 13.54 with the lowest score of 0 and the highest score of 27 . Average fatigue score of 20.7 with the lowest score of 9 the highest was 34. Anxiety $(p=0,001)$ and Stress $(\mathbf{p}=\mathbf{0 , 0 2 4 )}$ correlated with fatigue. The relationship between stress and fatigue shows a moderate relationship and a positive pattern, which means that the higher the stress level, the higher the patient's fatigue. The test results showed a significant relationship between stress and fatigue in patients. The relationship between anxiety and fatigue shows a moderate relationship with a positive pattern, meaning that the more anxious patients undergoing hemodialysis are, the more fatigue they are. Therefore, it can be concluded anxiety are determinant factor of fatigue in hemodyalisis patients. Keywords: Stress, anxiety, fatigue, hemodyalisi.s
\end{abstract}

\section{INTRODUCTION}

Hemodialysis is a kidney function replacement therapy that aims to remove metabolic waste or certain toxins from human blood circulation, such as water, sodium, potassium, hydrogen, urea, creatinine, uric acid, and other substances through a semi-permeable membrane as a blood separator and dialysate fluid in artificial kidneys where diffusion, osmosis, and ultrafiltration processes will occur [1]. Patients with chronic kidney failure who undergohemodialysis therapy will experience psychological problems, such as Disorders of Self-Concept, Anxiety, Depression, and Grief. Anxiety is a vague feeling of discomfort or fear that is accompanied by a response [2]. The results of research from a total of 62 respondents, $38.7 \%$ were seriously worried [3]. Meanwhile, from the results of research $45.5 \%$ are anxious [4]. According to [3], patients who have just undergone hemodialysis will feel anxious about the dialysis needle insertion, see the blood in the dialysis tube, and sound the dialysis unit alarm sound.

Patients undergoing hemodialysis every week need 12-15 hours for dialysis, or at least 3-4 hours per therapy [5]. This activity will continue throughout his life. How long the patient has had to undergo hemodialysis also affects the patient's anxiety. Patients with chronic renal failure who undergo hemodialysis often experience anxiety because of threats to their integrity where they often think that their disease will cause physiological disability and even death. The experience of someone who is lacking in hemodialysis therapy can be an important factor that can affect a 
person's psychological defense. This first experience is a very important and very decisive factor for mental conditionsin the future. If someone's experience is lacking about hemodialysis, it tends to affect the increase in anxiety when facing hemodialysis [5].The state of dependence on the dialysis machine throughout his life results in changes in the lives of people with CRF. Health status, economic conditions, and the hemodialysis process itself can affect changes in the patient's life, all of which are one of the triggers or causes of stress. These changes can be variables identified as stressors [6].

Stress in CKD patients can also be triggered because they have to undergo HD for life, not to mention having to face complications from the CRF disease itself such as heart and blood vessel system disorders, anemia, hypertension, fertility problems both men and women, skin and bone disorders and There are many more problems caused by CRF, which make patients feel anxious and stressed about the reality they have to face [7].

The most prominent negative impact in clients with end-stage kidney is fatigue or fatigue. Symptoms of fatigue (fatigue) have been associated with increased morbidity and mortality in end-stage renal failure clients undergoing hemodialysis [8].

With the impact caused by hemodialysis therapy, it was necessary to have the role of health workers to prevent negative effects from appearing and even predominantly affecting patients. Nurses need to pay attention to all aspects of the patient, from physical, psychological, social, and cultural to create holistic nursing care. Based on data from the existing problems, it is believed that hemodialysis has a significant impact on patient psychology. The aims of this study was to examine the relationship between stress, anxiety and fatigue in patients undergoing hemodialysis.

\section{METHODS}

This study designed as a cross sectional approach. The population is Hemodyalisis patient. The sample studies found 37 patients undergoing hemodialysis. The sample was taken using accidental sampling method. With inclusion criteria age more than 17 years, willing to be respondents. The exclusion criteria were neurological disorders and speech difficulties. Data collection using a questionnaire.

\section{RESULTS}

Table 1. Distribution of Hemodyalisis's patient by background characteristic.

\begin{tabular}{ccc}
\hline & Total & Percent \\
\hline Gender & & \\
Male & 16 & 43,2 \\
Female & 21 & 56,8 \\
Education & & \\
Low & 13 & 35,1 \\
High & 24 & 64,9 \\
\hline
\end{tabular}

Table 1 show the proportion of female respondents $(56.8 \%)$ are more than male. Higher education respondents were $64.9 \%$ more dominant than those with low education. Averageage 52.16 years, The relationship between anxiety and fatigue indicates a moderate relationship with a positive pattern, meaning that the more anxious patients undergoing hemodialysis are, the more fatigue they are. The test results showed a significant relationship between anxiety and fatigue in patients.

Tabel 2. Distribution of Responden who Underwent Hemodialysis by Age, Length of HD, anxiety, stress and fatigue scores.

\begin{tabular}{lcccc}
\hline Variable & Mean & SD & Min-Max & $95 \%$ CI \\
\hline Age & 52,16 & 13,06 & $24-78$ & $0,93-1,34$ \\
Duration & 32,95 & 42,142 & $1-168$ & $47,81-56,52$ \\
Anxiety & 10,11 & 6,168 & $0-20$ & $8,05-12,16$ \\
Stress & 13,54 & 6,715 & $0-27$ & $11,30-15,78$ \\
fatigue & 20,7 & 6,04 & $9-34$ & $18,77-22,80$ \\
\hline
\end{tabular}

Tabel 2 show average length of hemodialysis 32.95 months, Average anxiety score 10.11. The average stress score was 13.54. Average fatigue score of 20.7 with the lowest score 9 highest 34 . The average age of 52.16 years, with the lowest age being 24 years and the oldest being 78 years. The average length of hemodialysis was 32.95 months with the shortest being 1 month and the longest being 168 months. The average score of anxiety was 10.11 with the lowest score of 0 and the highest of 20 . The average score of stress was 13.54 with the lowest score of 0 and the highest score of 27. Average fatigue score of 20.7 with the lowest score of 9, the highest was 34 .

Table 3. Difference in Average Fatigue Rate of Respondents Undergoing Hemodialysis by Sex and Education

\begin{tabular}{cccccc}
\hline Variabel & Mean & SD & SE & $p$ value & $\mathrm{n}$ \\
\hline Gender & & & & & \\
Male & 18,56 & 5,62 & 1,40 & 0,049 & 16 \\
Female & 22,47 & 5,92 & 1,29 & & 21 \\
Education & & & & & \\
Low & 22.23 & 6,80 & 1,88 & 0,290 & 13 \\
High & 20.00 & 5,57 & 1,13 & & 24 \\
\hline
\end{tabular}


Table 4. Difference in Respondent Fatigue Level by Age and Stress in Hemodilysis Unit

\begin{tabular}{lcclc}
\hline Variabel & $\mathrm{R}$ & $\mathrm{R}^{2}$ & PersamaanGaris & $p$ value \\
\hline Age & 0,208 & 0,043 & $\begin{array}{l}\text { Fatigue }=15.771+0,0 ! \\
\text { usia }\end{array}$ & 0,217 \\
Stress & 0,37 & 0,137 & $\begin{array}{l}\text { Fatigue }=16,28- \\
0,33 \text { stres }\end{array}$ & 0,024 \\
\hline
\end{tabular}

The relation between age and fatigue shows a weak and positive pattern, which means that the older the patient is, the higher the fatigue. The test results showed no significant relation between age and fatigue in patients. $\mathrm{R}$ square is 0.043 , meaning that the regression line equation obtained can explain $4.3 \%$ of the variation in fatigue

The relationship between stress and fatigue shows a moderate and positive pattern, which means that the higher the stress level the higher the patient's fatigue. The test results show a significant relationship between stress and fatigue in patients. $\mathrm{R}$ square 0.137 means that the regression line equation obtained can explain the $13.7 \%$ variation in fatigue.

Table 5. Difference in Fatigue Level according to Hemodialysis and Anxiety

\begin{tabular}{lccc}
\hline \multicolumn{1}{c}{ Variable } & $\mathrm{r}$ & $p$ value & $n$ \\
\hline Duration & $-0,248$ & 0,139 & 37 \\
Anxiety & 0,503 & 0,001 & 37 \\
\hline
\end{tabular}

The relationship between anxiety and fatigue indicates a moderate relationship with a positive pattern, meaning that the more anxious patients undergoing hemodialysis are, the more fatigue they are. The test results showed a significant relationship between anxiety and fatigue in patients

The final model of multivariate analysis consists of five variables which all have a $\mathrm{p}$ value $<0.05$, but this model must go through an assumption test so that the line equation used produces valid numbers.

Table 6. Analysis of Modeling Variable Assumption Test on Fatique

\begin{tabular}{llclcc}
\hline Variabel & $\begin{array}{l}p \text { value } \\
\text { (ANOVA) }\end{array}$ & $\begin{array}{l}\text { Durbin } \\
\text { Watson }\end{array}$ & $\begin{array}{l}\text { coefficie } \\
n \text { ts } B\end{array}$ & $\begin{array}{l}\text { Standari } \\
\text { zed } \\
\text { coefficie } \\
\text { nts beta }\end{array}$ & VIF \\
\hline Sex & & & \multicolumn{3}{c}{} \\
Age & & & 1,596 & 0,132 & 1,280 \\
Duration & 0,021 & 1,338 & $-0,091$ & 0,197 & 1,160 \\
Anxiety & & & 0,400 & $-0,094$ & 1,214 \\
Stress & & & 0,0709 & 1,697 \\
\hline
\end{tabular}

Consecutively these values are as follows stress (0.078), HD duration (0.094), age (0.197), gender (0.132) and anxiety (0.403) Anxiety are determinant factor of fatigue in hemodyalisis patients.

\section{DISCUSSION}

Fatigue from the results of this study showed the average score was 20.7 (18.77 - 22.80), in contrast to the results of the study which stated that hemodialysis patients experienced severe fatigue [9]. This study observed several independent variables, namely gender, education, age, length of hemodialysis, anxiety and stress with the dependent variable fatigue. From the analysis, it was found that 3 variables had a significant relationship with fatigue, namely gender and ( $\mathrm{p}$ value 0.049 ), stress ( $\mathrm{p}$ value 0.024 ), and anxiety ( $\mathrm{p}$ value 0.001 ). While the variables age, education and length of hemodialysis did not show a significant relationship.The factors that contribute to fatigue, namely psychosocial factors, behavior, physical aspects and thought patterns [10]. Psychosocial factors are depression, anxiety, anger, frustration and shame.

After analyzing the 5 factors, namely age, gender, duration of hemodialysis, stress and anxiety, it was found that anxiety was the dominant factor in the occurrence of fatigue in hemodialysis patients. Anxiety [11] is a feeling of discomfort or fear accompanied by an autonomic response (the cause is often not specific or unknown to each individual)., suppressed emotions, physical and hereditary This feeling of anxiety is the result of self-anticipation of danger. Anxiety there are factors that influence the development of basic patterns of anxiety. There were Environmentcauses. that the anxiety experienced by patients undergoing hemodialysis was significantly related to social support [12]. Social support from family, friends and significant people. So it is stated that it is important to do a psycho-social evaluation for patients undergoing hemodialysis.

\section{CONCLUSION}

The study results showed a significant relationship between stress and fatigue, anxiety and fatigue. The relationship between stress and fatigue shows a moderate and positive pattern, which means that the higher the stress level the higher the patient's fatigue. The relationship between anxiety and fatigue indicates a moderate relationship with a positive pattern, meaning that the more anxious patients undergoing hemodialysis are, the more fatigue they ware. 
It is important to conduct an assessment of the psychological aspects of patients undergoing hemodialysis so that psychological problems can be determined and appropriate interventions for these psychological problems can be determined. Increasing its role in providing nursing care to hemodialysis patients, it is necessary to do nursing care that provides nursing interventions in dealing with psychological aspects including anxiety and stress.

\section{REFERENCES}

[1] Haryono. Keperawatan Medikal Bedah Sistem Perkemihan. Yogyakarta :Rapha Publishing. Yogyakarta: Rapha; 2013.

[2] Yusuf, A.H F, ,R \& Nihayati H. Buku Ajar Keperawatan Kesehatan Jiwa. Buku Ajar Keperawatan Kesehat Jiwa 2015:1-366. https://doi.org/ISBN 978-xxx-xxx-xx-X.

[3] Harahap SAJ, Yustina I, Ardinata D. FAKTOR-FAKTOR YANG BERHUBUNGAN DENGAN TINGKAT KECEMASAN PASIEN HEMODIALISIS DI RSUD Dr. PIRNGADI MEDAN. Idea Nurs J 2015;6:1-9.

[4] Manurung. Terapi Reminiscence: Solusi Pendekatan Sebagai Upaya Tindakan Keperawatan dalam Menurunkan Kecemasan, Stress dan Depresi. Jakarta: Trans Info Media; 2016.

[5] Jangkup JYK, Elim C, Kandou LFJ. Tingkat Kecemasan Pada Pasien Penyakit Ginjal Kronik (Pgk) Yang Menjalani Hemodialisis Di Blu Rsup Prof. Dr. R. D. Kandou Manado. E-CliniC

$2015 ; 3$. https://doi.org/10.35790/ecl.3.1.2015.7823.

[6] Yanti EK, Miswadi. Faktor-Faktor Yang Berhubungan Dengan Kecemasan Pada Hemodialisis Di Ruangan Hemodialisis Rsud Bengkalis Tahun 2016. J Ners 2018;2:28-40.

[7] Abbott KC, Glanton CW, Trespalacios FC, Oliver DK, Ortiz MI, Agodoa LY, et al. Body mass index, dialysis modality, and survival: Analysis of the United States Renal Data System Dialysis Morbidity and Mortality Wave II Study. Kidney Int 2004;65:597-605. https://doi.org/10.1111/j.1523-1755.2004.00385.x.

[8] Colvy J. Tips Cerdas Mengenali dan Mencegah Gagal Ginjal. Yogyakarta: Dafa Publishing; 2010.

[9] Bonner A, Caltabiano M, Berlund L. Quality of life, fatigue, and activity in Australians with chronic kidney disease: A longitudinal study. Nurs Heal Sci 2013;15:3607. https://doi.org/10.1111/nhs.12038.

[10] Jhamb M, Pike F, Ramer S, Argyropoulos C, Steel J, Dew $\mathrm{MA}$, et al. Impact of fatigue on outcomes in the hemodialysis (HEMO) study. Am J Nephrol 2011;33:51523. https://doi.org/10.1159/000328004.

[11] Picariello F, Moss-Morris R, MacDougall IC, Norton S, Da Silva-Gane M, Farrington K, et al. Cognitive-behavioural therapy (CBT) for renal fatigue (BReF): A feasibility randomised-controlled trial of CBT for the management of fatigue in haemodialysis (HD) patients. BMJ Open 2018;8. https://doi.org/10.1136/bmjopen-2017-020842.

[12] NANDA. Diagnosis Keperawatan ; Definisi dan Klasifikasi 2014 -2014. Jakarta: ECG; 2012. 